\title{
Oscar Is a Man: Sexism and the Academy Awards
}

\author{
Kenneth Grout \\ Owen Eagan \\ Emerson College (USA)
}

This study analyzes the implicit bias of the Academy Awards and Oscar's historic lack of gender equity. While there are awards for Best Actor and Actress, a comparative analysis of these awards and the Best Picture prize reveals that a man is more than twice as likely as a woman to receive an Oscar for leading work in a Best Picture. A man is also nearly twice as likely to be nominated as a leading performer in a Best Picture winner. Supporting women in Best Pictures fare a bit better with actual trophies, but, when considering nominations, a man is still more than oneand-a-half times as likely as a wom- an to be nominated for a supporting performance in a Best Picture winner. This research considers these factors, identifies potential reasons for them, and draws conclusions regarding the decades of gender bias in the Academy Awards. Further, this study investigates the dissolution of the Hollywood studio system and how, though brought on in part by two of the film industry's leading ladies, the crumbling of that system ultimately hurt the industry's women more than its men.

Keywords: Oscars, Academy Awards, sexism, gender inequity, Best Picture.

$\mathrm{T}$

he Academy Awards have been given out annually for 92 years to, among others, the top actor and actress as voted on by the members of the film academy. Even though the awards were not instituted to equalize the industry status of men and women, the Academy made the decision to give one to each (and, later, two to each), thus forcing a sense of gender democracy. The awards were to be symbols of artistic credibility; any synchronicity with boxoffice performance would be purely coincidental.

That said, the business impact of the award could not be denied. The Oscar (as the Academy Award has come to be called) has, over the years, proven to add significant dollars to the box office tallies of many films, although it is not always clear whether the Oscar follows the dollars or the dollars follow the Oscar. Some 
86 straightforward analysis says that if the Oscar follows the dollars, the performers in our most popular films would also be our most frequently lauded. On the other hand, if the dollars follow the Oscar, all performers would stand an equal chance of claiming the statue, since the statue itself - and neither the identity nor the draw of the actor or actress- would be the reason for the additional box office revenue.

If the Oscar were given out to films and performances based purely on box office revenue, talent would not matter. If the Oscar were given out on artistry alone, dollars would be irrelevant. Neither is exclusively the case, but when one examines the choices the Academy has made in selecting its Best Picture recipients over the years, an interesting statistic emerges: it is twice as likely that a Best Picture winner contains an Oscar-winning performance by a man than by a woman.

Why is it that such discrepancies have occurred and continue to occur? Why is it that the "best" projects of any given year so strongly favor men? There are many possible explanations. Perhaps the best roles are those for men. Perhaps more technical and promotional money is dedicated to films starring men. Perhaps the best writers are themselves men who tend to tell their own stories.

All of these factors likely play a role, and yet none is exhaustive. Unfortunately, little academic research has been done to assess why these imbalances exist. However, the differences in the types of roles afforded women and their shorter acting careers have been long recognized (Gilberg and Hines, 2000; Markson and Taylor, 1993). It is also well documented that women are significantly underrepresented in film and that they are underpaid compared to their male counterparts (Smith et al., 2019; Berg, 2015).

To assess the pervasive sexism at the very heart of the awards machine that is Oscar, one must examine the industry tension between money and creation, between product and art, between men and women. And, regardless of the exact ingredients to this recipe for prejudice, none speaks kindly of the way the film industry thinks of, compensates, or awards its women.

It is likely no coincidence that Oscar is a man.

\section{METHODOLOGY}

This study consists of a comparative analysis of the Academy Award for Best Actor, Best Actress, Best Supporting Actor and Best Supporting Actress with the Academy Award for Best Picture. The period analyzed is from the inception of the Academy of Motion Picture Arts and Sciences to the present day. This analysis was conducted using data provided by the Academy of Motion Picture Arts and Sciences and IMDb, the Internet Movie Database. The data is provided in the appendix and is contextualized throughout this paper as an annotated history of the awards is discussed. 
On May 16, 1929, the Academy of Motion Picture Arts and Sciences began giving out awards of merit to the films and performances it considered "best" from the previous year's crop. And, although the Academy has gone to great pains to ensure its process for award giving is unbiased, one fact is certain: the pictures honored as their year's best were twice as likely to include an Academy award-worthy performance by a man than by a woman. It may be that a great film begets a great performance or that a great performance helps ensure a great film, but whatever comes first — the acting or the movie — the Academy Awards' gender gap paints a disquieting portrait.

Of the 92 films to be awarded Best Picture of the Year (from Wings to Parasite), 27 of them contained the winner of the year's Best Actor award, while only 12 contained that year's best performance by an actress. Further, if only nominations were considered, 35 additional male performances were nominated for Best Actor that were included in the year's Best Picture winner, while only 19 such performances by women have been nominated. This results in a total of 62 to 31 , in favor of the men, either nominated or winning leading performances included in Best Picture winners.

While leading ladies may not have been as often included in the Best Pictures, surely their supporting counterparts -along with the nurses, girlfriends, secretaries, and wisecracking neighbors they brought to life- were garnering more attention and praise in the Best Picture winning films. While the number of winning supporting performances in the year's Best Picture has been essentially even [17 to 13 in favor of the men], again the nominated performance tally is overwhelmingly male. While 45 supporting performances by men in the Best Picture winner were nominated for (but did not receive) recognition, only 27 such performances by women made the same grade. In total, then, the camp of supporting roles made a more balanced picture than the leading role tallies, but not much: 62-to-40 again in favor of the men.

In all, then, 124 men won or were nominated for either leading or supporting roles in Best Picture winners, as opposed to 71 women, or 57 percent of the men. It is impossible to pin responsibility for this reality on one source alone, but the picture it paints certainly gives credence to that old Hollywood line: "There's no good parts for women" (Abramovitch, 2008). To understand possible issues at the problem's core requires a visit back to the beginning of the Academy and the very reasons for its formation.

In the early years of the last century, Hollywood was becoming a thriving factory town, turning out hundreds of film products per year, most of which were devoured by the American viewing public, still fascinated by the very wonder of the moving picture. By the mid-1920s, the industry was changing -in part, because it was finally beginning to think of itself as an industry. As a result, the notion of unionism was moving into southern California. Actors, writers, and directors were all thinking it was about time their interests got formalized consideration from the likes of the town's studio heads. Before it was possible for these 
notions to get much footing within the industry, the biggest studio head of them all - Louis B. Mayer- decided to do something about it.

Mayer, along with "leading man Conrad Nagel, director Fred Niblo and Fred Beetson, head of the Association of Motion Picture Producers" (Wiley and Bona, 1986), formed an exclusive club that would hold annual banquets for the most prominent affiliates from the five branches of the industry - actors, writers, directors, producers, and technicians - personally invited by Mayer himself. He selected thirty-six leading Hollywood lights as charter members of what would be known as the Academy of Motion Picture Arts and Sciences. Of those thirty-six, thirty-three were men. The three women were two writers and one on-screen performer: Mary Pickford. Even though she was an actress, it was Pickford's business acumen that Mayer was rewarding by her inclusion; Pickford joined the producer's branch of the Academy, as one of the founders of the United Artists studio.

With Pickford on board as a producer, there were no women representing the profession of acting in the Academy at its inception.

The Academy held a formal banquet meeting during its first year and a subsequent membership drive to generate interest. During its second year, it decided to give out awards of merit. Janet Gaynor received the first Leading Actress statue for her work in three films: $7^{\text {th }}$ Heaven, Street Angel, and Sunrise. The young Gaynor was only twenty-one at the time and lived with her mother in Los Angeles. Her competitors for that first award - Gloria Swanson and Louise Dresser- were, respectively, the thrice-divorced mistress of Joseph Kennedy, and the forty-seven-year-old wife of a $20^{\text {th }}$ Century Fox studio booking agent. As for the leading male that first year, the trophy went to Switzerland's Emil Jannings, a forty-fouryear-old silent film star whose American film career was, thanks to the talkies and his thick German accent, about to die. The runner-up and only other nominee, Richard Barthelmess, was one of the original handpicked thirty-six. Even in that first year of self-congratulating, Hollywood established clearly one standard for the women and another for the men.

The third year of the Academy's existence saw the second awards given out and the very first Academy Awards scandal. At this time, all members of the Academy were able to nominate, but it was left to a Central Board of Judges to select the actual winner from among the nominees. And it was the five members of that Central Board of Judges who were invited, during the nominating season, to tea at Pickfair, the home of founding Academy members Douglas Fairbanks and his wife, the Oscar-nominated Mary Pickford, actress.

A few weeks later, Mary became the second leading lady honored with the Academy statuette, garnering recognition for her role in Coquette. The tea served at Pickfair that day must have been particularly potent, though, since that Central Board of Judges was alone in its assessment of Mrs. Fairbanks' work. Few liked the movie and even fewer admired Pickford's performance in it. Accusations of favoritism rang out; as a result, the Academy dismantled the Central Board of Judges and, starting the following year, each Academy member was eligible to vote on the final ballot. In the wake of scandal and backlash, the Academy was finding its footing with change and growth. 
The Academy would begin to represent the opinions of its ever-varying membership; during the 1935 ceremony honoring 1934's films, several firsts happened: the Best Picture of the Year was handed to a comedy, Columbia Pictures' It Happened One Night; the lead actor and actress awards were given for performances in the same film, Clark Gable and Claudette Colbert for It Happened One Night; and the awards for leading actor and leading actress were given for performances in the Best Picture winner. It Happened One Night, in fact, garnered the top five prizes: Best Picture, Director, Leading Actor, Leading Actress, and Screenplay. It would take forty-one years for another film to repeat that feat (1975's One Flew over the Cuckoo's Nest) and, in fact, it has happened only one other time (1991's The Silence of the Lambs). The trend for even one of the leading performers in the year's best film to also garner individual recognition had not truly begun in 1934, so the breadth of the acclaim given It Happened One Night was both unprecedented and unexpected.

During the first decade of the Academy Awards, the coalescence between leading performer and honored film did happen more than in 1934: in 19281929, at the first awards, the Best Picture prize was divided into two categories: Production and Artistic Quality of Production. One of the films for which Janet Gaynor won was Sunrise, which took the prize for Artistic Quality of Production. Not until the seventh awards, with the It Happened One Night sweep, were any more trophies given to leading actors and actresses for their work in the year's Best Picture. Two years after It Happened One Night, though, in 1936, Luise Rainer won for her performance in the year's Best Picture, The Great Ziegfeld.

Another woman would accomplish this in 1939, when Vivien Leigh garnered note for her Scarlett O'Hara in the year's best, Gone with the Wind. Another three years passed and again a woman received an award for her performance in the year's Best Picture: Greer Garson in 1942's Mrs. Miniver. After Mrs. Miniver, it would take more than three decades for another woman to receive a Best Actress trophy for the year's Best Picture.

This was due, in part, to the end of World War II in 1945 and the acceleration of the studio system's dissolution in 1948, both pivotal events in the world of film.

The culmination of World War II not only brought the soldiers home, it brought their stories with them. Male-dominated tales ruled the Best Picture roost until 1950, and all six of the Best Pictures so named between 1944 and 1949 saw their leading men nominated for Best Actor and, in five of those six cases, take the prize home. All of a sudden, the women who had carried the industry through the thirties - Irene Dunne, Myrna Loy, Norma Shearer, Shirley Temple - and through the war years - Greer Garson, Bette Davis, Ingrid Bergman, Olivia de Havilland - were either being relegated to lesser parts in lesser productions or had left the industry altogether.

The studio system in Hollywood had been the only game in town since before the dawn of the talking picture in the late 1920s. The term studio system referred to "A business model adopted by Hollywood studios that combined all facets of film production with studio-owned distribution chains" (Hollywood Lexicon, 2019). The system — and its extermination — would ultimately play a critical role in furthering Oscar's sexist practices. 
To the first point, studios spent a great deal of their resources locating, training, and grooming their contractees to become household names. All film performers who worked in the United States between the 1920s and 1948 toiled under the studio system. One of eight studios would hold their contract. While the artist may have been lent out to other houses for certain projects, their employer - their home in the industry - was the single studio to whom they were contracted. Studios in the old system told their players what projects they were making and whom they were working with; artists - even major ones- possessed only moderate choice in the work they did. Artists came to represent their studio as much as they did the picture or themselves; studios, as a result, developed and refined their own reputations.

To this end, studios made sure that all their employees — male and femaleprovided an appropriate return on investment. The promotion of female-led projects was just as resolute as that of male-led vehicles, and the renewal of talent contracts was left exclusively in the hands of the studios.

The dissolving of the studio system was in the works for years before it finally happened, beginning probably when the United States Justice Department attacked the practice of vertical integration in all industries under the Sherman Antitrust Act as early as 1912 (Thornton, 1996). Still, film scholars point to several decisive events within the film industry when discussing the cessation of the studio system. They involve Bette Davis, Olivia de Havilland and a decision by the United States Supreme Court.

\section{BETTE DAVIS SAILS FOR BETTER PARTS}

In 1937, Bette Davis had an Oscar under her belt for Dangerous, but she was having trouble convincing Warner Brothers to get her consistently good parts or to loan her to studios where quality opportunities beckoned. While many stars believed they should have more control over the direction of their careers, Bette was the first big name to do something about it. Her bosses at Warner actually made it an easy decision for her: "When Warner Brothers assigned her to play an axe-wielding lumberjack, Davis refused. The studio suspended her, and she sailed to England" (Jones, 2005). Davis accepted work from a British producer, and Jack Warner sued her for breach-of-contract. Warner won the case, "creating the image of a spoiled actress seeking a bigger paycheck, not better parts... but Jack had only wanted to teach his girl a lesson" (Jones, 2005). Even though Warner won the battle, it was Davis who won the war: "She got better material. Her big 1938 vehicle was Jezebel, the drama of a Southern belle... (with) Henry Fonda as her leading man... and William Wyler as director" (Wiley and Bona, 1986). The part would go on to win Davis her second Oscar. While she did not subsequently have carte blanche at the studio, her stand against the system allowed her to play a greater role in her career going forward and opened the door for other artists to do the same. 
After garnering two Oscar nominations, actress Olivia de Havilland went to her studio (again, Warner Brothers) and asked for "more substantial roles" (Encyclopedia Britannica, 2019). The studio not only refused, they suspended the star for six months. At the conclusion of Olivia's contract, Warner insisted she work an extra six months to make up for the suspension. Though their demand went against the laws of the state of California, many in Hollywood had accepted just that sort of mandate in the past. De Havilland decided, instead, to challenge not only the studio but also the entire belief that actors were merely studio property; she did not appear on-screen during the two-year court battle that ensued. Finally, the ruling came in favor of de Havilland, stating that all performers were to be limited to a seven-year contract based on calendar years, not actual time spent working. De Havilland's legal victory reduced the power of the studios and extended greater creative freedom to performers. "The decision was one of the most significant and far-reaching legal rulings in Hollywood, and came to be informally known, and is still known to this day, as the "de Havilland law'" (Belloni, 2007).

\section{THE UNITED STATES v. PARAMOUNT PICTURES, INC. 334 US 131 (1948)}

This Supreme Court case found that the major studios had been guilty for years of antitrust violations and required them to immediately divest their holdings and to discontinue the practice of block booking. This truly was the death knell for the studio system, exacerbated further when then-head-of-RKO Howard Hughes immediately complied with the divestiture ruling, thus forcing the other studios' hands (The Society of Independent Motion Picture Producers, 2019). The end of the studio system would ultimately mean great freedom for actors but, while the structure had been torment for some, it had meant security and consistency for others. Actor Cesar Romero spoke for many players when he said, "After all those years of being under contract to a studio...the future seemed dark, having always had the protection of a studio before" (Liedle, 2007).

The termination of the studio system came at the same time as another monumental threat to the film industry: television. With fewer ticket sales, thanks to television, the industry made fewer movies (Library of Congress, 2019). By the 1960s, the studio system had completely wound down, and "Films addressing women's concerns continued to be made, but they were often harder to fund, distribute, and exhibit within the changing Hollywood economy" (Library of Congress, 2019). As the advent of the action hero began to capture more attention and, thus, dollars, some films in this genre were successfully led by women but too infrequently: "Harkening back to the days of silent serials, women appropriated the role of action heroes in many contemporary films, among them Alien (1979), The Terminator (1984), and Thelma and Louise (1991), but more often they appeared as appendages to male stars" (Library of Congress, 2019). 
One of the most significant impacts brought about by these changes was the shift away from the women's stories of the late 1930s and early 1940s to the male-centric film landscape that, thanks in large part to a man named Brando, had only just begun.

\section{FROM KOWALSKI TO CORLEONE}

As Elvis was to the airwaves, Marlon Brando was to the silver screen... strutting, smoldering, and sweating his way into the American consciousness. Five of his eight Oscar nominations came during the 1950s, the decade during which he reigned uncontested. His Stanley Kowalski's howl from 1951's A Streetcar Named Desire remains the undying image representing that classic film on the American landscape. He garnered his first Oscar win for his remarkable turn in 1954's best film, On the Waterfront.

Brando brought a style of acting to the screen previously unseen outside the Broadway stage. His method, his nuance, his manner - both inspired and inspiring - established his influence in the work of everyone from James Dean to Paul Newman; this was no longer Cagney, the Gangster, or Cooper, the Tough Guy, or Wayne, the Hero, or Stewart, the Everyman. This was the proclamation of something new: something dangerous and enthralling that would captivate American film audiences for the next two decades. To say the era of the male-dominated film was bookended by Stanley Kowalski and Don Corleone would not be an overstatement.

Brando's win in the Best Picture of the year was one of four times Oscar's Best Actor was in the Best Picture during the decade of the 1950s; it also happened in 1955 (Ernest Borgnine, Marty), 1957 (Alec Guinness, The Bridge on the River Kwai), and 1959 (Charlton Heston, Ben-Hur). Add on the five times during the late 1940s that the top male performance of the year was featured in the Oscar-winning Best Picture and you have nine times in sixteen years that male-centric pictures took home the top prize in Hollywood while their leading men each snagged an individual trophy.

This is not to say the era of women's pictures was entirely dead and gone. Some brilliant work by women was happening during this time, but it never garnered a trophy in a picture that also took home the top Academy honor. Consider 1950, the year when three of the greatest female performances of all time were competing for the Oscar, all in Oscar-nominated best films. Judy Holliday in Born Yesterday received the Best Actress award, topping Gloria Swanson in Sunset Boulevard and Bette Davis in the year's top picture, All about Eve. Other ageless performances by women during this period included Shirley Booth in Come Back, Little Sheba, Vivien Leigh as the quintessential Blanche DuBois in A Streetcar Named Desire, and Anna Magnani in Tennessee Williams' The Rose Tattoo. For all the individual acclaim these women were garnering, their pictures themselves were not taking home the big Oscar prize, even if, like A Streetcar Named Desire and The Rose Tattoo, they were nominated. 
The artistic vehicles for these women certainly were not second-rate. Still, the films that were winning Best Picture of the year during this time - save All About Eve in 1950 and the musicals An American in Paris in 1951 and Gigi in 1958were either pictures focused on men (Going My Way, The Lost Weekend, The Best Years of Our Lives, All the King's Men, From Here to Eternity, Marty, Ben-Hur, among others) or entertainment extravaganzas (The Greatest Show on Earth, Around the World in Eighty Days).

During the 1960s, there were three more years when the Best Actor of the year appeared in the year's Best Film: in 1964, it was Rex Harrison in My Fair Lady; in 1966, Paul Scofield in A Man for All Seasons; and in 1967, Rod Steiger in In the Heat of the Night. Although women were nominated for their leading performances in Best Pictures throughout the decade, none of the ladies and features shared the honor.

The 1970s finally brought a drop of rain to the female draught when two women garnered Best Actress Oscars in the year's Best Pictures (1975, Louise Fletcher in One Flew over the Cuckoo's Nest, and 1977, Diane Keaton in Annie Hall). These were the first such honors since Greer Garson in Mrs. Miniver nearly thirty-five years earlier. In fact, since Jack Nicholson won the leading actor Oscar for One Flew over the Cuckoo's Nest, it took from 1942 all the way until Keaton's 1977 triumph for a picture to win Best Actress and Best Picture without pulling in the Best Actor Oscar, as well.

Despite the seeming abundance of female glory during the 1970s, it was truly a decade whose first half was dominated by more male-focused stories. In fact, the first three years of the decade saw the year's Best Actor appear in the year's Best Picture: George C. Scott in Patton, Gene Hackman in The French Connection, and Marlon Brando in The Godfather. The men would rule twice more in the decade, with Nicholson in 1975 and Dustin Hoffman in Kramer vs. Kramer four years later.

The 1980s were ushered in with the decidedly male Raging Bull garnering Best Actor, but it was the family drama Ordinary People, which walked off with 1980's Best Picture Oscar. The Best Actor did gain the prize in the year's Best Picture three times during the decade, but the classic loner/lawman/gangster/working stiff portrayals of years gone by fell in the way of a lawyer turned peacemaker (Ben Kingsley in Gandhi, 1982), a composer (F. Murray Abraham in Amadeus, 1984), and an autistic savant (Dustin Hoffman in Rain Man, 1988).

During the same decade, two leading female performances claimed victory in Best Picture winners: Shirley MacLaine in Terms of Endearment and Jessica Tandy in Driving Miss Daisy. While it could be argued that neither of the characters MacLaine and Tandy played was revelatory in advancing the cause of women, the two wins were critical: the 1980s was the first period since the 1930s that the Best Actress appeared in the Best Picture twice in the same decade.

The 1990s saw three wins for the men in the Best Picture winners (Anthony Hopkins in The Silence of the Lambs, Tom Hanks in Forrest Gump, and Kevin Spacey in American Beauty) and another two such wins for the ladies: Jodie Foster for 1991's The Silence of the Lambs, and Gwyneth Paltrow for 1998's Shakespeare in Love. 
Along came 2000. The first year of this new age saw the Best Picture of the Year Oscar go to Gladiator, and its Best Actor trophy to Maximus, Russell Crowe. That film was the only picture of that decade to receive both the Best Picture and Best Actor trophies. It also happened just once for the women, when Hilary Swank was named Best Actress for the Best Picture-winning Million Dollar Baby.

The decade of 2010s initially kept up the same old pattern. Its first two years (2010, 2011) saw Best Picture of the Year honors awarded to the film featuring the year's Best Performance by an Actor in a Leading Role: Colin Firth in The King's Speech and Jean Dujardin in The Artist. As the decade progressed, three other men were nominated for (but did not win) Best Leading Actor in the year's Best Picture. During this same time, only one woman (Sally Hawkins) was nominated for a leading performance in a Best Picture winner (2017's The Shape of Water). No other leading actor or actress performances came from their year's Best Picture winner.

\section{CONCLUSION}

From the beginning of the film industry, men have held inordinate influence while women have played subordinate roles. The reasons for and impacts of this reality have been considered in detail in this paper. When viewed through a contemporary lens, the mores and decisions that helped shape filmmaking as a business often appear now to have been misguided at best. Still, one thing is historically certain: women have had to work harder than men to achieve the same acclaim, the same paycheck, and the same access to prestige projects. While some responsibility for this rests at the feet of the moguls who established the industry, the opportunities for women seem to be even fewer now than when the Warners and the Mayers and the Goldwyns set up shop in the desert a century ago.

Regardless of the future for women in the world of filmmaking, it is critical that the Academy of Motion Picture Arts and Sciences remember its Oscar mission: to honor, with awards of merit, works of substance and quality. If the Academy cheapens the honor and rusts the statue by continuing to favor its focus on predominantly male-centric films, how long can its prestige and legitimacy survive in the shadow of its own biases?

The answer to that question, and the actions that come at the hands of its consideration, will determine Oscar's relevance for future generations of artists, critics, financiers, and fans alike.

Kenneth Grout (kenneth_grout@emerson. edu) is an affiliated faculty member in the Department of Communication Studies at Emerson College. Prior to earning his M. Ed. in Interdisciplinary Studies from Cambridge College,
Ken studied Writing and Literature in Emerson's Graduate School and received his BME from Drake University in Des Moines, Iowa. For years, Ken worked in corporate and government sectors before joining Emerson's Communication 
Studies Department within the past decade. His focus has been public speaking and oral presentation of literature. Ken has written and performed successful one-man character shows, has

Owen Eagan (owen_eagan@emerson.edu) specializes in measuring and assessing strategic communications in business and political environments. This includes utilizing traditional and evolving theoretical and analytical approaches to gauge the efficacy of various forms of communication from interpersonal to mass media communication. Based on his academic research, his book entitled Oscar Buzz and the Influence of World of Mouth on Mo- written several produced plays, and authored the book And the Winner Really Is, a reference manual utilizing new methods to rank Academy Award nominees and winners.

vie Success was published by Palgrave Macmillan in April 2020. In addition to serving as a faculty member at Emerson, Owen Eagan serves as a Senior Vice President for Consensus Strategies, a management consulting firm that specializes in strategic advocacy services for leading corporate and institutional clients. He received a BA from Clark University, an MA from Emerson College, and an MBA from Pepperdine University.

\section{References}

Abramovitch, Seth (2008). "Critics Insist 'The Women' Sets Back Chick Flick's Rights Several Hundred Years". Available at <http:// gawker.com/5048558/critics-insist-thewomen-sets-back-chick-flicks-rights-severalhundred-years $>$. Accessed 5 October 2019.

Belloni, Matthew (2007). "De Havilland Lawsuit Resonates Through Hollywood". Reuters. Available at: <http://www.reuters. com/article/2007/08/24/industry-lawsuit-dcidUSN2329585820070824>. Accessed 5 October 2019 .

Berg, Madeline (2015). "Everything You Need to Know About the Hollywood Pay Gap". Forbes. Available at: <https://www. forbes.com/sites/maddieberg/2015/11/12/ everything-you-need-to-know-about-thehollywood-pay-gap/\#4e97642c5cf1>. Accessed 5 October 2019.

Box Office Mojo (2019). "Top Lifetime Adjusted Grosses". Available at: <https://www. boxofficemojo.com/chart/top_lifetime_gross_ adjusted/?adjust_gross_to $=2020 \&$ ref_ $=$ bo cso_ac>. Accessed 5 October 2019.
Encyclopedia Britannica (2019). "Olivia de Havilland". Available at: <http://www. britannica.com/EBchecked/topic/153543/ Olivia-de-Havilland>. Accessed 5 October 2019.

Gilberg, Michael and Hines, Terence (2000). "Male Entertainment Award Winners Are Older than Female Winners". Psychological Reports, vol. 86.

Hollywood Lexicon (2019). "Studio System". Available at: <www.hollywoodlexicon.com/ studiosystem.html>. Accessed 5 October 2019.

Jones, Peter (2005). Stardust: The Bette Davis Story [DVD].

Library of Congress. "American Women: Resources from the Moving Image Collections". Available at: <http://memory.loc. gov/ammem/awhhtml/awmi10/post_studio. html\#top>. Accessed 5 October 2019.

Markson, Elizabeth W. and Taylor, Carol A. (1993). "Real versus Reel World: Older Women and the Academy Awards". Women \& Therapy, vol. 14, pp. 157-172.

Smith, Stacy L.; Choueiti, Marc; Pieper, Katherine; Yao, Kevin; Case, Ariana, and Choi, 
Angel (2019). "Inequality in 1,200 Popular Films: Examining Portrayals of Gender, Race/ Ethnicity, LGBTQ \& Disability". USC Annenberg Inclusion Initiative. Available at <http:// assets.uscannenberg.org/docs/aii-inequalityreport-2019-09-03.pdf>. Accessed 5 October 2019.

The Society of Independent Motion Picture Producers. "The Independent Producers and the Paramount Case, 1938-1949". Avai- lable at: <http://www.cobbles.com/simpp archive/paramountcase_6supreme1948.htm>. Accessed 5 October 2019.

Thornton, Mark (1996). "How Antitrust Ruined the Movies". Mises Institute. Available at: <https://mises.org/library/how-antitrustruined-movies-0>. Accessed 5 October 2019.

Wiley, Mason and Bona, Damien (1986). Inside Oscar. New York, NY: Ballantine Books.

\section{Appendix}

The following chart identifies all winners of the Best Picture Oscar since the awards' inception. Further, acting performances within those Best Picture winners are identified; those actors and actresses highlighted in yellow are those that won the year's Oscar in their category in that year's Best Picture. Those highlighted in blue were nominated for (but did not win) acting honors in that year's Best Picture. When no one is noted in a given category for a given year, it means that there was not a nominee from that year's Best Picture winner in that acting category; when more than one performance is identified within the same or different categories, it is because multiple performances from the Best Picture winner were so honored.

\begin{tabular}{l|l|l|l|l|l} 
YR & LEAD ACTR & LEAD ACTS & SUP ACTR & SUP ACTS & BEST PICTURE \\
\hline $1927 / 1928$ & & Janet Gaynor & N/A & N/A & Wings/Sunrise \\
\hline $1928 / 1929$ & & Bessie Love & N/A & N/A & $\begin{array}{l}\text { The Broadway } \\
\text { Melody }\end{array}$ \\
\hline $1929 / 1930$ & & & N/A & N/A & $\begin{array}{l}\text { All Quiet on the } \\
\text { Western Front }\end{array}$ \\
\hline $1930 / 1931$ & Richard Dix & Irene Dunne & N/A & N/A & Cimarron \\
\hline $1931 / 1932$ & & & N/A & N/A & Grand Hotel \\
\hline $1932 / 1933$ & & Diana Wynyard & N/A & N/A & Cavalcade \\
\hline 1934 & Clark Gable & $\begin{array}{l}\text { Claudette } \\
\text { Colbert }\end{array}$ & N/A & N/A & $\begin{array}{l}\text { It Happened } \\
\text { One Night }\end{array}$ \\
\hline 1935 & Clark Gable & & N/A & N/A & $\begin{array}{l}\text { Mutiny on the } \\
\text { Bounty }\end{array}$ \\
\hline & & & & & \\
\hline & Charles & & & & \\
\hline
\end{tabular}




\begin{tabular}{|c|c|c|c|c|c|}
\hline YR & LEAD ACTR & LEAD ACTS & SUP ACTR & SUP ACTS & BEST PICTURE \\
\hline & Franchot Tone & & & & \\
\hline 1936 & & Luise Rainer & & & $\begin{array}{l}\text { The Great } \\
\text { Ziegfeld }\end{array}$ \\
\hline 1937 & Paul Muni & & $\begin{array}{l}\text { Joseph } \\
\text { Schildkraut }\end{array}$ & & $\begin{array}{l}\text { The Life of Emile } \\
\text { Zola }\end{array}$ \\
\hline 1938 & & & & Spring Byington & $\begin{array}{l}\text { You Can't Take } \\
\text { It with You }\end{array}$ \\
\hline \multirow[t]{2}{*}{1939} & Clark Gable & Vivien Leigh & $\begin{array}{l}\text { Thomas } \\
\text { Mitchell }\end{array}$ & Hattie McDaniel & $\begin{array}{l}\text { Gone with the } \\
\text { Wind }\end{array}$ \\
\hline & & & & $\begin{array}{l}\text { Olivia de } \\
\text { Havilland }\end{array}$ & \\
\hline 1940 & Laurence Olivier & Joan Fontaine & & Judith Anderson & Rebecca \\
\hline 1941 & & & Donald Crisp & Sara Allgood & $\begin{array}{l}\text { How Green Was } \\
\text { My Valley }\end{array}$ \\
\hline 1942 & Walter Pidgeon & Greer Garson & Van Heflin & Teresa Wright & Mrs. Miniver \\
\hline 1943 & $\begin{array}{l}\text { Humphrey } \\
\text { Bogart }\end{array}$ & & Claude Rains & & Casablanca \\
\hline \multirow[t]{2}{*}{1944} & Bing Crosby & & Barry Fitzgerald & & Going My Way \\
\hline & Barry Fitzgerald & & & & \\
\hline 1945 & Ray Milland & & & & $\begin{array}{l}\text { The Lost } \\
\text { Weekend }\end{array}$ \\
\hline 1946 & Frederic March & & Harold Russell & & $\begin{array}{l}\text { The Best Years } \\
\text { of Our Lives }\end{array}$ \\
\hline \multirow[t]{2}{*}{1947} & Gregory Peck & $\begin{array}{l}\text { Dorothy } \\
\text { McGuire }\end{array}$ & & Celeste Holm & $\begin{array}{l}\text { Gentleman's } \\
\text { Agreement }\end{array}$ \\
\hline & & & & Anne Revere & \\
\hline 1948 & Laurence Olivier & & & Jean Simmons & Hamlet \\
\hline 1949 & $\begin{array}{l}\text { Broderick } \\
\text { Crawford }\end{array}$ & & John Ireland & $\begin{array}{l}\text { Mercedes } \\
\text { McCambridge }\end{array}$ & $\begin{array}{l}\text { All the King's } \\
\text { Men }\end{array}$ \\
\hline \multirow[t]{2}{*}{1950} & & Ann Baxter & $\begin{array}{l}\text { George } \\
\text { Sanders }\end{array}$ & Celeste Holm & All About Eve \\
\hline & & Bette Davis & & Thelma Ritter & \\
\hline 1951 & & & & & $\begin{array}{l}\text { An American in } \\
\text { Paris }\end{array}$ \\
\hline 1952 & & & & & $\begin{array}{l}\text { The Greatest } \\
\text { Show on Earth }\end{array}$ \\
\hline
\end{tabular}




\begin{tabular}{|c|c|c|c|c|c|c|}
\hline 98 & YR & LEAD ACTR & LEAD ACTS & SUP ACTR & SUP ACTS & BEST PICTURE \\
\hline 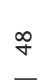 & 1953 & $\begin{array}{l}\text { Montgomery } \\
\text { Clift }\end{array}$ & Deborah Kerr & Frank Sinatra & Donna Reed & $\begin{array}{l}\text { From Here to } \\
\text { Eternity }\end{array}$ \\
\hline \multirow{21}{*}{ 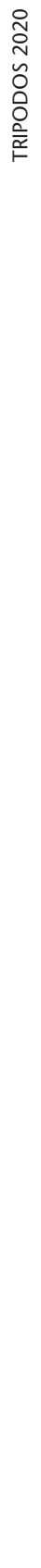 } & & Burt Lancaster & & & & \\
\hline & 1954 & Marlon Brando & & Lee J. Cobb & Eva Marie Saint & $\begin{array}{l}\text { On the } \\
\text { Waterfront }\end{array}$ \\
\hline & & & & Karl Malden & & \\
\hline & & & & Rod Steiger & & \\
\hline & 1955 & Ernest Borgnine & & Joe Mantell & Betsy Blair & Marty \\
\hline & 1956 & & & & & $\begin{array}{l}\text { Around the } \\
\text { World in } 80 \\
\text { Days }\end{array}$ \\
\hline & 1957 & Alec Guinness & & $\begin{array}{l}\text { Sessue } \\
\text { Hayakawa }\end{array}$ & & $\begin{array}{l}\text { The Bridge on } \\
\text { the River Kwai }\end{array}$ \\
\hline & 1958 & & & & & Gigi \\
\hline & 1959 & Charlton Heston & & Hugh Griffith & & Ben-Hur \\
\hline & 1960 & Jack Lemmon & $\begin{array}{l}\text { Shirley } \\
\text { MacLaine }\end{array}$ & Jack Kruschen & & The Apartment \\
\hline & 1961 & & & $\begin{array}{l}\text { George } \\
\text { Chakiris }\end{array}$ & Rita Moreno & West Side Story \\
\hline & 1962 & Peter O'Toole & & Omar Sharif & & $\begin{array}{l}\text { Lawrence of } \\
\text { Arabia }\end{array}$ \\
\hline & 1963 & Albert Finney & & Hugh Griffith & Diane Cilento & Tom Jones \\
\hline & & & & & $\begin{array}{l}\text { Dame Edith } \\
\text { Evans }\end{array}$ & \\
\hline & & & & & Joyce Redman & \\
\hline & 1964 & Rex Harrison & & $\begin{array}{l}\text { Stanley } \\
\text { Holloway }\end{array}$ & Gladys Cooper & My Fair Lady \\
\hline & 1965 & & Julie Andrews & & Peggy Wood & $\begin{array}{l}\text { The Sound of } \\
\text { Music }\end{array}$ \\
\hline & 1966 & Paul Scofield & & Robert Shaw & Wendy Hiller & $\begin{array}{l}\text { A Man for All } \\
\text { Seasons }\end{array}$ \\
\hline & 1967 & Rod Steiger & & & & $\begin{array}{l}\text { In the Heat of } \\
\text { the Night }\end{array}$ \\
\hline & 1968 & & & Jack Wild & & Oliver! \\
\hline & 1969 & Dustin Hoffman & & & Sylvia Miles & $\begin{array}{l}\text { Midnight } \\
\text { Cowboy }\end{array}$ \\
\hline
\end{tabular}




\begin{tabular}{|c|c|c|c|c|c|}
\hline YR & LEAD ACTR & LEAD ACTS & SUP ACTR & SUP ACTS & BEST PICTURE \\
\hline & Jon Voight & & & & \\
\hline 1970 & George C. Scott & & & & Patton \\
\hline 1971 & Gene Hackman & & Roy Scheider & & $\begin{array}{l}\text { The French } \\
\text { Connection }\end{array}$ \\
\hline \multirow[t]{3}{*}{1972} & Marlon Brando & & James Caan & & The Godfather \\
\hline & & & Robert Duvall & & \\
\hline & & & Al Pacino & & \\
\hline 1973 & Robert Redford & & & & The Sting \\
\hline \multirow[t]{3}{*}{1974} & Al Pacino & & Robert DeNiro & Talia Shire & $\begin{array}{l}\text { The Godfather, } \\
\text { Part II }\end{array}$ \\
\hline & & & $\begin{array}{l}\text { Michael V. } \\
\text { Gazzo }\end{array}$ & & \\
\hline & & & Lee Strasberg & & \\
\hline 1975 & Jack Nicholson & Louise Fletcher & Brad Dourif & & $\begin{array}{l}\text { One Flew over } \\
\text { Cuckoo's Nest }\end{array}$ \\
\hline \multirow[t]{2}{*}{1976} & $\begin{array}{l}\text { Sylvester } \\
\text { Stallone }\end{array}$ & Talia Shire & $\begin{array}{l}\text { Burgess } \\
\text { Meredith }\end{array}$ & & Rocky \\
\hline & & & Burt Young & & \\
\hline 1977 & Woody Allen & Diane Keaton & & & Annie Hall \\
\hline 1978 & Robert de Niro & & $\begin{array}{l}\text { Christopher } \\
\text { Walken }\end{array}$ & Meryl Streep & $\begin{array}{l}\text { The Deer } \\
\text { Hunter }\end{array}$ \\
\hline \multirow[t]{2}{*}{1979} & Dustin Hoffman & & Justin Henry & Meryl Streep & $\begin{array}{l}\text { Kramer vs. } \\
\text { Kramer }\end{array}$ \\
\hline & & & & Jane Alexander & \\
\hline 1980 & & $\begin{array}{l}\text { Mary Tyler } \\
\text { Moore }\end{array}$ & $\begin{array}{l}\text { Timothy } \\
\text { Hutton }\end{array}$ & & Ordinary People \\
\hline 1981 & & & Ian Holm & & Chariots of Fire \\
\hline 1982 & Ben Kingsley & & & & Gandhi \\
\hline \multirow[t]{2}{*}{1983} & & $\begin{array}{l}\text { Shirley } \\
\text { MacLaine }\end{array}$ & Jack Nicholson & & $\begin{array}{l}\text { Terms of } \\
\text { Endearment }\end{array}$ \\
\hline & & Debra Winger & John Lithgow & & \\
\hline \multirow[t]{2}{*}{1984} & $\begin{array}{l}\text { F. Murray } \\
\text { Abraham }\end{array}$ & & & & Amadeus \\
\hline & Tom Hulce & & & & \\
\hline
\end{tabular}




\begin{tabular}{|c|c|c|c|c|c|c|}
\hline 100 & YR & LEAD ACTR & LEAD ACTS & SUP ACTR & SUP ACTS & BEST PICTURE \\
\hline $\begin{array}{l}\stackrel{\infty}{+} \\
-\end{array}$ & 1985 & & Meryl Streep & $\begin{array}{l}\text { Klaus Maria } \\
\text { Brandauer }\end{array}$ & & Out of Africa \\
\hline \multirow{20}{*}{ 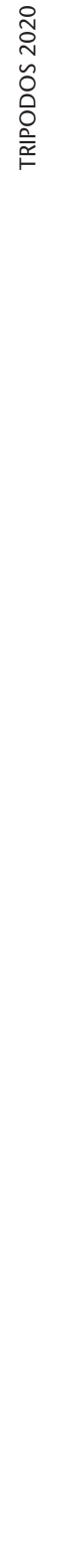 } & 1986 & & & Tom Berenger & & Platoon \\
\hline & & & & Willem Dafoe & & \\
\hline & 1987 & & & & & $\begin{array}{l}\text { The Last } \\
\text { Emperor }\end{array}$ \\
\hline & 1988 & Dustin Hoffman & & & & Rain Man \\
\hline & 1989 & $\begin{array}{l}\text { Morgan } \\
\text { Freeman }\end{array}$ & Jessica Tandy & Dan Aykroyd & & $\begin{array}{l}\text { Driving Miss } \\
\text { Daisy }\end{array}$ \\
\hline & 1990 & Kevin Costner & & $\begin{array}{l}\text { Graham } \\
\text { Greene }\end{array}$ & $\begin{array}{l}\text { Mary } \\
\text { McDonnell }\end{array}$ & $\begin{array}{l}\text { Dancing with } \\
\text { Wolves }\end{array}$ \\
\hline & 1991 & $\begin{array}{l}\text { Anthony } \\
\text { Hopkins }\end{array}$ & Jodie Foster & & & $\begin{array}{l}\text { The Silence of } \\
\text { the Lambs }\end{array}$ \\
\hline & 1992 & Clint Eastwood & & Gene Hackman & & Unforgiven \\
\hline & 1993 & Liam Neeson & & Ralph Fiennes & & Schindler's List \\
\hline & 1994 & Tom Hanks & & Gary Sinise & & Forrest Gump \\
\hline & 1995 & & & & & Braveheart \\
\hline & 1996 & Ralph Fiennes & $\begin{array}{l}\text { Kristin Scott } \\
\text { Thomas }\end{array}$ & & Juliette Binoche & $\begin{array}{l}\text { The English } \\
\text { Patient }\end{array}$ \\
\hline & 1997 & & Kate Winslet & & Gloria Stuart & Titanic \\
\hline & 1998 & & $\begin{array}{l}\text { Gwyneth } \\
\text { Paltrow }\end{array}$ & Geoffrey Rush & Judi Dench & $\begin{array}{l}\text { Shakespeare in } \\
\text { Love }\end{array}$ \\
\hline & 1999 & Kevin Spacey & Annette Bening & & & $\begin{array}{l}\text { American } \\
\text { Beauty }\end{array}$ \\
\hline & 2000 & Russell Crowe & & $\begin{array}{l}\text { Joaquin } \\
\text { Phoenix }\end{array}$ & & Gladiator \\
\hline & 2001 & Russell Crowe & & & $\begin{array}{l}\text { Jennifer } \\
\text { Connelly }\end{array}$ & $\begin{array}{l}\text { A Beautiful } \\
\text { Mind }\end{array}$ \\
\hline & 2002 & & $\begin{array}{l}\text { Renee } \\
\text { Zellweger }\end{array}$ & John C. Reilly & $\begin{array}{l}\text { Catherine Zeta- } \\
\text { Jones }\end{array}$ & Chicago \\
\hline & & & & & Queen Latifah & \\
\hline & 2003 & & & & & $\begin{array}{l}\text { LOTR: Return of } \\
\text { the King }\end{array}$ \\
\hline
\end{tabular}

2 LOTR = Lord of the Rings. The trilogy was released in 2001, 2002, and 2003; only the 


\begin{tabular}{|c|c|c|c|c|c|}
\hline YR & LEAD ACTR & LEAD ACTS & SUP ACTR & SUP ACTS & BEST PICTURE \\
\hline 2004 & Clint Eastwood & Hilary Swank & $\begin{array}{l}\text { Morgan } \\
\text { Freeman }\end{array}$ & & $\begin{array}{l}\text { Million Dollar } \\
\text { Baby }\end{array}$ \\
\hline 2005 & & & Matt Dillon & & Crash \\
\hline 2006 & & & Mark Wahlberg & & The Departed \\
\hline 2007 & & & Javier Bardem & & $\begin{array}{l}\text { No Country for } \\
\text { Old Men }\end{array}$ \\
\hline 2008 & & & & & $\begin{array}{l}\text { Slumdog } \\
\text { Millionaire }\end{array}$ \\
\hline 2009 & Jeremy Renner & & & & The Hurt Locker \\
\hline 2010 & Colin Firth & & Geoffrey Rush & $\begin{array}{l}\text { Helena Bonham } \\
\text { Carter }\end{array}$ & $\begin{array}{l}\text { The King's } \\
\text { Speech }\end{array}$ \\
\hline 2011 & Jean Dujardin & & & Bérénice Bejo & The Artist \\
\hline 2012 & & & Alan Arkin & & Argo \\
\hline 2013 & Chiwetel Ejiofor & & $\begin{array}{l}\text { Michael } \\
\text { Fassbender }\end{array}$ & Lupita Nyong'O & 12 Years a Slave \\
\hline 2014 & Michael Keaton & & Edward Norton & Emma Stone & Birdman \\
\hline 2015 & & & Mark Ruffalo & $\begin{array}{l}\text { Rachel } \\
\text { McAdams }\end{array}$ & Spotlight \\
\hline 2016 & & & Mahershala Ali & Naomi Harris & Moonlight \\
\hline 2017 & & Sally Hawkins & Richard Jenkins & Octavia Spencer & $\begin{array}{l}\text { The Shape of } \\
\text { Water }\end{array}$ \\
\hline 2018 & $\begin{array}{l}\text { Viggo } \\
\text { Mortensen }\end{array}$ & & Mahershala Ali & & Green Book \\
\hline 2019 & & & & & Parasite \\
\hline
\end{tabular}

\section{TOTALS}

Lead Actor winners in Best Picture winners

Lead Actor nominees in Best Picture winners

Supporting Actor winners in Best Picture winners

Supporting Actor nominees in Best Picture winners

TOTAL MALE ACTORS HONORED IN BEST PICTURE WINNERS

Lead Actress winners in Best Picture winners

Lead Actress nominees in Best Picture winners 
KENNETH GROUT, OWEN EAGAN

INDIVIDUAL PERFORMANCES HONORED (AS \% OF TOTAL): 